\title{
Analisis Kinerja Penyuluh Pertanian Lapangan dalam Program Lembaga Distribusi Pangan Masyarakat di Kecamatan Makarti Jaya Kabupaten Banyuasin, Sumatera Selatan
}

\section{Analysis of Field Extension Worker's Perfomance in the Program of Community Food Distribution Institution in Makarti Jaya District, Banyuasin Regency, South Sumatera}

\author{
Muhammad Arbi ${ }^{1}$, Sriati $^{2}$ \\ ${ }^{1}$ Jurusan Sosial Ekonomi Pertanian, Fakultas Pertanian, Universitas Sriwijaya \\ ${ }^{2}$ Dosen Jurusan Sosial Ekonomi Pertanian, Fakultas Pertanian, Universitas Sriwijaya
}

\begin{abstract}
The Ministry of Agriculture implements the Program of Community Food Distribution Institutionto empower farmer groups in staple food distribution. The objectives of this research were : 1) to describe Agricultural Extension Worker's perfomance in Makarti Jaya District, Banyuasin Regency, 2) to measure Agricultural Extension Worker's performance in LDPM program, 3) to determine the level of success of LDPM, and 4) to analyze the relationship between the Agricultural Extension Worker's (PPL) perfomance and level of success of the LDPM.This study was conducted in Makarti Jaya District, Banyuasin Regency in March-Mei 2016, using a survey method and a disproportionate stratified random sampling method. Farmer samples taken were 45 farmers in 9 farmer groups. The data were processed in tabulation and analyzed by using Spearman correlation test. The study results showed that PPL perfomance in District of Makarti Jaya, Regency of Banyuasin was in a sufficient category with the average performance level of 71,43. PPL Performance in LDPM was in the medium category with the average score of 19,02. Meanwhile, the level of success in the LDPM program was in a high category with the average score of 21,58 (successful). The resulted Spearman correlation test showed there was arelationship between PPL performance and the level of success in LDPM programin Makarti Jaya District, Banyuasin Regency.
\end{abstract}

Keyword: Performance, PPL, farmer groups, LDPM

\section{Abstrak}

Kementerian Pertanian melaksanakan Program Lembaga Distribusi Pangan Masyarakat (LDPM) dalam rangka memberdayakan kelompok tani dalam distribusi makanan pokok di masyarakat. Tujuan dari penelitian ini adalah: 1) untuk menggambarkan kinerja Penyuluh Pertanian di Kecamatan Makarti Jaya Kabupaten Kabupaten Banyuasin, 2) untuk mengukur kinerja Penyuluh Pertanian Lapangan (PPL) dalam program LDPM, 3) untuk mengukur tingkat keberhasilan LDPM, dan 4) untuk menganalisis hubungan antara dari kinerja PPL dengan tingkat keberhasilan LDPM. Penelitian ini dilakukan di Kecamatan Makarti Jaya Kabupaten Banyuasin pada Maret - Mei 2016. Penelitian ini menggunakan metode survei dengan pengambilan sampel sebanyak 45 petani dari 9 kelompok tani dengan menggunakan teknik dispropotional random sampling. Data diolah dalam bentuk tabulasi dan diuji dengan menggunakan Uji Korelasi Rank Spearman. Hasil penelitian menunjukkan bahwa kinerja PPL di Kecamatan Makarti Jaya Kabupaten Banyuasin masuk dalam kategori cukup baik dengan skor 71,43. Kinerja PPL dalam melaksanakan program LDPM di daerah tersebut masuk dalam kategori sedang dengan jumlah skor 19,02, dan tingkat keberhasilan program LDPM di daerah tersebut masuk dalam kategori tinggi dengan skor 21,58 (berhasil). Hasil analisis Uji Korelasi Rank Spearman menunjukkan bahwa terdapat hubungan antara kinerja PPL dengan tingkat keberhasilan pelaksanaan program LDPM di Kecamatan Makarti Jaya Kabupaten Banyuasin.

Kata Kunci: Kinerja, PPL, kelompok tani, LDPM

\section{Pendahuluan}

Dampak dari permasalahan petani, Poktan dan Gapoktan dalam mengolah, menyimpan dan memasarkan hasil produksinya dapat menyebabkan ketidakstabilan harga di wilayah sentra produksi pertanian pada saat terjadi panen raya, sehingga harga cenderung turun sampai tingkat yang kurang menguntungkan petani. Sebaliknya pada saat musim paceklik terjadi kekurangan pangan sehingga harga cenderung meningkat dan tetntunya akan

\footnotetext{
${ }^{1}$ Korespondensi penulis

E-mail: arbiunsri@yahoo.com
}

memberatkan konsumen.

Lembaga Distribusi Pangan Masyarakat (LDPM) merupakan suatu lembaga yang dibentuk oleh pemerintah melalui program pemberdayaan Gapoktan yang diharapkan mampu mengembangkan unit usaha distribusi atau pengolahan hasil dan unit pengelola cadangan pangan, pengembangan agribisnis, dan meningkatkan nilai tambah produk petani. Gapoktan atau gabungan kelompok tani adalah organisasi yang memperkuat kelembagaan petani yang ada, sehingga pembinaan pemerintah 
terhadap petani akan terfokus dengan sasaran yang jelas. Gapoktan menjadi gateway institutions yang menjadi penghubung petani satu desa dengan lembaga-lembaga diluarnya.

Kinerja Penyuluh Pertanian Lapangan (PPL) menjadi faktor penentu keberhasilan suatu program, khususnya Program LDPM. Kinerja sama artinya dengan performance. Performance ialah hasil kerja atau prestasi kerja. Bagi seorang penyuluh pertanian, kinerja merupakan perwujudan diri atas sejauh mana tugas pokoknya dapat dilaksanakan sesuai dengan patokan yang telah ditetapkan. PPL sebagai pendamping dalam Program LDPM mempunyai tugas dan tanggung jawab yaitu dalam kegiatan penyuluhan dan evaluasi serta pelaporan terkait program tersebut sehingga tinggi rendahnya kinerja penyuluh pertanian akan berdampak pada tingkat keberhasilan program LDPM.

Adapun tujuan penelitian ini adalah untuk mendeskripsikan kinerja PPL di Kecamatan Makarti Jaya Kabupaten Banyuasin, mengukur kinerja PPL dalam program LDPM, mengetahui tingkat keberhasilan program LDPM, serta menganalisis hubungan kinerja PPL terhadap tingkat keberhasilan program LDPM di Kecamatan Makarti Jaya Kabupaten Banyuasin.

\section{Metode Penelitian}

Metode yang digunakan dalam penelitian ini adalahmetode penelitian survei. Menurut Singarimbun dan Effendi (1995), ciri khas metode penelitian ini adalah data yang dikumpulkan dari responden yang banyak jumlahnya dengan menggunakan kuesioner. Metode ini digunakan karena jumlah populasi petani yang besar sehingga tidak memungkinkan untuk meneliti secara langsung seluruh petani.

Sampel yang dipilih untuk mewakili seluruh anggota populasi adalah petani yang tergabung dalam Gapoktan Sri Rejeki yang menjalankan program Lembaga Distribusi Pangan Masyarakat (LDPM) di Kecamatan Makarti Jaya Kabupaten Banyuasin. Penelitian ini bersifat deskriptif sehingga dapat menjelaskan bagaimana tingkat kinerja PPL dalam program Lembaga Distribusi Pangan Masyarakat (LDPM) serta bagaimana tingkat keberhasilan program tersebut berdasarkan penilaian petani. Pengambilan sampel dilakukan dengan metode disproporsionate stratified random sampling dengan mengambil sebanyak 5 petani dari setiap kelompok tani yang tergabung dalam Gapoktan Sri Rejeki yang mengikuti program LDPM (Tabel 1).

Tabel 1. Populasi dan Sampel Penelitian yang Tergabung dalam Gapoktan Sri Rejeki Kabupaten Banyuasin

\begin{tabular}{clcc}
\hline No. & Kelompok Tani & Populasi & Sampel \\
\hline 1. & Sadar jaya & 36 & 5 \\
2. & Sri Bangun & 47 & 5 \\
3. & Sri Makmur I & 34 & 5 \\
4. & Sri Makmur II & 33 & 5 \\
5. & Sri Rejeki II & 32 & 5 \\
6. & Sri Dadi I & 32 & 5 \\
7. & Tri Tnggal & 41 & 5 \\
8. & Sri Dadi II & 32 & 5 \\
9. & Sri Lestari & 26 & 5 \\
\hline Jumlah & 313 & 45 \\
\hline
\end{tabular}

Sumber : BP3K Makarti Jaya

Data yang diperoleh di lapangan dari hasil wawancara langsung dari petani contoh diolah secara tabulasi dan hasilnya dipaparkan dalam bentuk tabel dan dianalisa secara deskriptif yaitu dengan memaparkan hasil yang didapat dalam bentuk uraian yang sistematis pada pembahasan. Untuk mengukur kinerja Penyuluh Pertanian Lapangan (PPL), dan tingkat keberhasilan program Lembaga Distribusi Pangan Masyarakat (LPDM) dilakukan dengan metode skoring dan diuraikan secara deskriptif. Penentuan tingkat kinerja penyuluh pertanian dan tingkat keberhasilan program Lembaga Distribusi Pangan Masyarakat (LPDM) dengan kriteria, tinggi, sedang, rendah dapat dilihat dengan menggunakan interval kelas.

Menjawab tujuan pertama penelitian yaitu mendeskripsikan kinerja Penyuluh Pertanian Lapangan di Kecamatan Makarti Jaya Kabupaten Banyuasin dilakukan analisis deskriptif dan skoring. Pengukuran kinerja PPL berdasarkan Permentan No 91 Tahun 2013 tentang Pedoman Evaluasi Kinerja Penyuluh Pertanian yaitu dengan melihat bagaimana pelaksanaan kinerja penyuluh pertanian lapangan. Ada 3 indikator yang digunakan untuk melihat kinerja PPL yaitu Persiapan Penyuluhan Pertanian, Pelaksanaan Penyuluhan Pertanian, dan Evaluasi dan Pelaporan. Tiga indikator tersebut berisikan 16 pertanyaan. Setiap pertanyaan dinilai dengan menggunakan skala 1 sampai dengan 5 . 
Skala 1 menunjukkan kinerja paling rendah dan skala 5 menunjukkan kinerja paling tinggi. Jumlah nilai pengukuran kinerja PPL disebut dengan Nilai Evaluasi Mandiri (NEM) yang merupakan ukuran prestasi kerja. Tata cara penghitungan kinerja PPL adalah sebagai berikut :

$$
\mathrm{NPK}=(\text { Total NEM }) / 80 \mathrm{x} 100
$$

di mana:

NPK : Nilai Prestasi Kerja / Kinerja PPL

Total NEM : Jumlah keseluruhan Nilai Evaluasi Mandiri

Standar NPK PPL dinyatakan dalam angka dan sebutan, seperti yang tertuang pada Tabel 2 sebagai berikut;

Tabel 2. Tabel Standar NPK (Nilai Prestasi Kerja/ Kinerja) PPL

\begin{tabular}{ccl}
\hline No. & Nilai & Prestasi Kerja \\
\hline 1 & $>91$ & Sangat Baik \\
2 & $76-90$ & Baik \\
3 & $61-75$ & Cukup \\
4 & $51-60$ & Kurang \\
5 & $<50$ & Buruk
\end{tabular}

Sumber : Permentan No 91 Tahun 2013 tentang Pedoman Evaluasi Kinerja Penyuluh Pertanian

Menjawab tujuan kedua yaitu mengukur mengukur kinerja Penyuluh Pertanian Lapangan (PPL) dalam program Lembaga Distribusi Pangan Masyarakat (LDPM) di Kecamatan Makarti Jaya Kabupaten Banyuasin dilakukan dengan metode skala Likert yang diukur melalui 2 indikator yaitu Kegiatan Penyuluhan/pendampingan dan Evaluasi dan Pelaporan. Setiap indikator tersebut diukur melalui 5 pertanyaan. Setiap pertanyaan diberi skor 3 untuk kriteria tinggi, skor 2 untuk kriteria sedang dan skor 1 untuk kriteria rendah, sehingga total skor tertinggi adalah 30 dan skor terendah adalah 10 .

Rumus yang dipakai untuk interval kelas adalah :

$$
\begin{array}{ll}
\mathrm{NR} & =\mathrm{NST}-\mathrm{NSR} \\
\mathrm{PI} & =\mathrm{NR}: \mathrm{JIK}
\end{array}
$$

di mana :
NR : Nilai Range

NST : Nilai Skor Tertinggi

NSR : Nilai Skor Terendah

PI : Panjang Interval

JIK : Jumlah Interval Kelas

Perhitungan untuk membuat interval kelas total untuk setiap indikator adalah sebagai berikut :

$\mathrm{NST}=(2$ indikator $\mathrm{x} 5$ pertanyaan $\mathrm{x}$ bobot pertanyaan 3 )

$=30$

$\mathrm{NSR}=(2$ indikator $\mathrm{x} 5$ pertanyaan $\mathrm{x}$ bobot pertanyaan 1)

$$
=10
$$

$\mathrm{JIK}=3$

$\mathrm{NR}=\mathrm{NST}-\mathrm{NSR}$

$=30-10$

$=20$

PI $\quad=$ NR : JIK

$=20: 3$

$=6,66$

Perhitungan untuk membuat interval kelas untuk setiap indikator adalah sebagai berikut :

$$
\begin{aligned}
\text { NST } & =(5 \text { pertanyaan } x \text { bobot pertanyaan } 3) \\
& =15 \\
\text { NSR } & =(5 \text { pertanyaan } x \text { bobot pertanyaan } 1) \\
& =5 \\
\text { JIK } & =3 \\
\text { NR } & =\mathrm{NST}-\mathrm{NSR} \\
& =15-5 \\
& =10 \\
\text { PI } & =N R: J I K \\
& =10: 3 \\
& =3,33
\end{aligned}
$$

Perhitungan membuat interval kelas untuk setiap pertanyaan adalah sebagai berikut:

$$
\begin{aligned}
\text { NST } & =(1 \text { pertanyaan } x \text { bobot pertanyaan } 3) \\
& =3 \\
\text { NSR } & =(1 \text { pertanyaan } x \text { bobot pertanyaan } 1) \\
& =1 \\
\text { JIK } & =3 \\
\text { NR } & =N S T-N S R \\
& =3-1 \\
\text { PI } & =2 \\
& =N R: J I K
\end{aligned}
$$




$$
\begin{aligned}
& =2: 3 \\
& =0,66
\end{aligned}
$$

Menjawab tujuan ketiga yaitu untuk mengukur tingkat keberhasilan program Lembaga Distribusi Pangan Masyarakat (LDPM) di Kecamatan Makarti Jaya Kabupaten Banyuasin juga dilakukan dengan metode skala Likert yang diukur melalui 3 indikator : hasil, manfaat dan dampak. Setiap indikator terdapat 3 pertanyaan sehingga total pertanyan berjumlah 9 pertanyaan. Setiap pertanyaan diberi skor 3 untuk kriteria tinggi, skor 2 untuk kriteria sedang, dan skor 1 untuk kriteria rendah. Dengan demikian, total skor tertinggi tingkat persepsi petani terhadap tingkat keberhasilan program LDPM adalah 27 dan total skor terendah adalah 9. Rumus yang dipakai untuk membuat interval kelas adalah:

$$
\begin{array}{ll}
\mathrm{NR} & =\mathrm{NST}-\mathrm{NSR} \\
\mathrm{PI} & =\mathrm{NR}: \mathrm{JIK}
\end{array}
$$

di mana :

NR : Nilai Range

NST : Nilai Skor Tertinggi

NSR : Nilai Skor Terendah

PI : Panjang Interval

JIK : Jumlah Interval Kelas

Perhitungan untuk membuat interval kelas total untuk setiap indikator adalah sebagai berikut :

NST $=(3$ indikator $\mathrm{x} 3$ pertanyaan $\mathrm{x}$ bobot pertanyaan 3 )

$$
=27
$$

$\mathrm{NSR}=(3$ indikator $\mathrm{x} 3$ pertanyaan $\mathrm{x}$ bobot pertanyaan 1)

$$
=9
$$

$\mathrm{JIK}=3$

$\mathrm{NR}=\mathrm{NST}-\mathrm{NSR}$

$=27-9$

$=18$

PI $\quad=$ NR : JIK

$=18: 3$

$=6$

Perhitungan untuk membuat interval kelas untuk indikator 1 adalah sebagai berikut :

NST $=(3$ pertanyaan $\mathrm{x}$ bobot pertanyaan 3$)$ $=9$

$$
\begin{aligned}
\text { NST } & =(3 \text { pertanyaan } x \text { bobot pertanyaan } 1) \\
& =3 \\
\text { JIK } & =3 \\
\text { NR } & =\mathrm{NST}-\mathrm{NSR} \\
& =9-3 \\
& =6 \\
\mathrm{PI} \quad & =\mathrm{NR}: \mathrm{JIK} \\
& =6: 3 \\
& =2
\end{aligned}
$$

Perhitungan membuat interval kelas untuk setiap pertanyaan adalah sebagai berikut :

NST $=(1$ pertanyaan $\mathrm{x}$ bobot pertanyaan 3$)$

$=3$

NST $=(1$ pertanyaan $\mathrm{x}$ bobot pertanyaan 1$)$

$=1$

$\mathrm{JIK}=3$

$\mathrm{NR}=\mathrm{NST}-\mathrm{NSR}$

$=3-1$

$=2$

PI $\quad=$ NR : JIK

$=2: 3$

$=0,66$

Menjawab tujuan keempat yaitu menganalisis hubungan kinerja Penyuluh Pertanian Lapangan (PPL) dengan tingkat keberhasilan program Lembaga Distribusi Pangan Masyarakat (LDPM) di Kecamatan Makarti Jaya Kabupaten Banyuasin, maka digunakan analisis korelasi rank Spearman dengan hipotesis sebagai berikut :

Ho : Tidak ada hubungan antara kedua variabel

Ha : Ada hubungan antara kedua variabel

Kaidah dalam pengambilan keputusan:

$z$ hitung $<z \alpha(\mathrm{n}) \quad=$ Terima Ho

$z$ hitung $z \alpha(\mathrm{n}) \quad=$ Tolak Ho atau terima Ha di mana $=0,05$

\section{Hasil dan Pembahasan}

\section{Kinerja Penyuluh Pertanian Lapangan dalam Tupoksi}

Keberadaan petugas penyuluh pertanian lapangan (PPL) saat ini sangat dibutuhkan dalam mendukung pembangunan pertanian khususnya dalam rangka turut menjaga stok kebutuhan pangan nasional. Kiprah seorang petugas penyuluh 
pertanian dimulai dari awal melakukan kegiatan usahatani bahkan dimulai dari penentuan keputusan komoditi apa yang akan dibudidayakan atau yang layak dibudidayakan oleh petani. Kinerja Penyuluh PPL di Kecamatan Makarti Jaya dalam tupoksinya didasarkan pada Permentan No 91 Tahun 2013 yang terdiri dari 3 indikator diukur melalui 16 parameter yang dapat dilihat pada Tabel 3.

Berdasarkan indikator pertama yaitu persiapan penyuluhan pertanian, PPL Kecamatan Makarti Jaya sudah dikategorikan cukup baik. Hal tersebut terbukti karena PPL sepenuhnya sudah membuat data potensi wilayah dan agroekosistem berupa adanya peta wilayah binaan, peta dan potensial wilayah binaan, adanya rencana jadwal kegiatan penyuluhan di masing-masing wilayah binaan. PPL juga selalu membuat RKTPP (Rencana Kerja Tahunan Penyuluh Pertanian dan menyusun program pertanian secara bersama-sama. Selain hal tersebut PPL juga ikut berperan aktif berupa bimbingan dalam penyusunan RDKK (Rencana Defenitif Kebutuhan Kelompok) kepada setiap kelompok tani yang berada dalam wilayahbinaan PPL. Penyusunan RDKK dilaksanakan secara musyawarah oleh Pengurus kelompok tani, anggota, dan PPL sebagai pembimbing. RDKK yang biasa disusun secara bersama yaitu RDKK Pupuk Bersubsidi dan Bantuan Benih. Selain hal tersebut, PPL juga sangat berperan aktif dalam peningkatan kapasitas petani, peningkatan kelas kelompok tani, dan penumbuhan kelompok tani baru.

Dalam kegiatan penyuluhan pertanian, PPL di BP3K Kecamatan Makarti juga tergolong cukup baik. Hal ini dapat terlihat dari hasil penilaian PPL sendiri.
Dalam melaksanakan desminasi/penyebaran materi penyuluhan, sebenarnya PPL sudah menyebarkan materi. Desminasi/ penyebaran materi yang diberikan PPL berupa dan melaksanakan penerapan metode penyuluhan dalam bentuk kunjungan/tatap muka tetapi PPL sendiri mengakui bahwa PPL kurang responsif dalam menganalisis penerapan penyuluhan di lapangan. Kegiatan evaluasi dan pelaporan dalam kegiatan penyuluhan memang sudah dilaksanakan oleh PPL. Tetapi kegiatan evaluasi dan pelaporan yang melibatkan petani masih kurang intens. Evaluasi dan pelaporan yang melibatkan petani hanya dilakukan dua kali dalam setahun yaitu pada saat musim tanam dan pasca panen. Sebagaimana yang telah ditampilkan pada tabel di atas, bahwa tingkat kinerja PPL di Kecamatan Makarti Jaya berada pada kriteria cukup. Untuk lebih jelasnya mengenai kinerja PPL dalam tugas dan fungsinya di Kecamatan Makarti Jaya dapat dilihat pada Tabel 3.

\section{Kinerja Penyuluh Pertanian Lapangan (PPL) dalam Program Lembaga Distribusi Pangan Masyarakat (LDPM)}

Kinerja Penyuluh Pertanian Lapangan dalam Program LPDM diukur melalui 2 indikator berdasarkan penilaian dari Penyuluh Pertanian Lapangan (PPL) sendiri dan penilaian petani yang mengikuti program LDPM tersebut. Indikator pengukuran terhadap kinerja PPL yaitu berdasarkan kegiatan penyuluhan dalam program LDPM serta pelaporan dan evaluasi dalam program LDPM (Tabel 4).

Tabel 3. Pengukuran Rata-rata Kinerja PPL dalam Tupoksinya di Kecamatan Makarti Jaya

\begin{tabular}{ccccccl}
\hline \multirow{2}{*}{ No } & \multicolumn{2}{c}{ Indikator Kinerja PPL } & & & \multicolumn{1}{c}{ Tingkat } \\
\cline { 2 - 4 } & $\begin{array}{c}\text { Persiapan } \\
\text { Penyuluhan Pertanian }\end{array}$ & $\begin{array}{c}\text { Pelaksanaan } \\
\text { Penyuluhan Pertanian }\end{array}$ & $\begin{array}{c}\text { Evaluasi } \\
\text { Pelaporan }\end{array}$ & Total NEM & NPK & \\
\hline 1 & 20 & 26 & 6 & 52 & 65,00 & Cukup \\
2 & 20 & 28 & 3 & 51 & 63,75 & Cukup \\
3 & 20 & 30 & 5 & 55 & 68,75 & Cukup \\
4 & 20 & 33 & 3 & 56 & 70,00 & Cukup \\
5 & 20 & 40 & 10 & 70 & 87,50 & Baik \\
6 & 20 & 21 & 3 & 44 & 55,00 & Kurang \\
7 & 20 & 42 & 10 & 72 & 90,00 & Baik \\
Total & 140 & 220 & 40 & 400 & & \\
\hline Rerata & 20 & 31,43 & 5,71 & 57,14 & 71,43 & Cukup \\
\hline
\end{tabular}


Tabel 4. Penilaian Tingkat Kinerja PPL dalam Program LDPM menurut Penilaian PPL di Kabupaten Banyuasin

\begin{tabular}{clccrc}
\hline \multirow{2}{*}{ No } & \multirow{2}{*}{ Indikator } & \multicolumn{2}{c}{ Penilaian PPL } & \multicolumn{2}{c}{ Persepsi Petani } \\
\cline { 3 - 6 } & & Skor & Kriteria & Skor & Kriteria \\
\hline 1 & Kegiatan Penyuluhan Pertanian & 12 & Tinggi & 9,67 & Sedang \\
2 & Pelaporan Dan Evaluasi & 11 & Sedang & 9,35 & Sedang \\
\hline Total & 23 & Sedang & 19,02 & Sedang \\
\hline
\end{tabular}

Berdasarkan penilaian PPL, tingkat kinerjanya dalam kegiatan penyuluhan pertanian berada pada kriteria sedang dengan total skor 12,00 . Hal tersebut diukur dari lima pengukuran melalui indikator kegiatan penyuluhan pertanian. Pada kenyataannya, PPL mengakui bahwa sudah mengatur jadwal dan memberikan materi yang berhubungan dengan program LDPM seperti materi untuk peningkatan setiap unit usaha yang diusahakan oleh Gapoktan Sri Rejeki. Sementara materi yang diberikan PPL kepada petani berupa arahan kepada petani untuk menjual hasil pangannya ke lumbung LDPM sehingga akhirnya petani terbantu untuk memperoleh harga produksi yang lebih baik disaat panen raya. Pelaporan dan evaluasi merupakan suatu kegiatan yang penting dilihat dari segi manfaatnya yaitu sebagai upaya memperbaiki dan penyempurnaan program/ kegiatan penyuluhan pertanian sehingga lebih efektif, efisien dan dapat mencapai tujuan yang telah ditetapkan. Pelapporan dan evaluasi dapat digunakana untuk memperbaiki perencanaan program dan kinerja penyuluhan, mempertanggungjawabkan kegiatan yang dilaksanakan, dan membandingkan antara kegiatan yang dicapai dengan tujuan yang telah ditetapkan.

Dalam melaksanakan tugas dan fungsinya sebagai pendamping program LDPM, penyuluh pertanian perlu dilakukan evaluasi atau penilaian terhadap kinerja PPL. Penilaian tersebut bisa dilakukan melalui diri sendiri. Tetapi selain itu, PPL juga perlu diberi penilaian atas kinerjanya melalui orang-orang yang menjadi subjek kegiatan penyuluhannya. Orang-orang tersebut adalah petani. Pada tabel berikut dijelaskan bangaimana persepsi petani terhadap kinerja PPL dalam kegiatan penyuluhan pertanian untuk program LDPM. Dalam melakukan tugasnya sebagai pendampingan saat mengirim laporan dan pembuatan pembukuan, PPL hanya melakukan pendampingan kepada Gapoktan dan Kelompoktani saja serta hanya sedikit petani yang mengetahui pembukuan lumbung pangan LDPM secara jelas. Tetapi dalam kegiatan memfasilitasi proses pembelian maupun pembelian gabah dan beras, banyak petani yang mengakui bahwa PPL membantu/memfasilitas kegiatan tersebut. Biasanya, PPL menganjurkan petani untuk menjual beras/gabah ke lumbung pangan LDPM tersebut.

Berdasarkan hasil penelitian, tingkat kinerja PPL dalam kegiatan penyuluhan program LDPM berdasarkan persepsi kelompok tani madya berada pada kriteria sedang dengan tingkat kinerja dalam kegiatan penyuluhan sebesar 8,93. Sementara berdasarkan hasil penelitian, tingkat kinerja PPL dalam kegiatan penyuluhan program LDPM berdasarkan persepsi kelompok tani lanjut berada pada kriteria sedang dengan tingkat kinerja dalam kegiatan penyuluhan sebesar 10,03. Tingkat kinerja PPL dalam evaluasi program LDPM berdasarkan kelompok tani madya berada pada kriteria sedang dengan skor 8,67 dan kelompok tani lanjut berada pada kriteria sedang dengan skor 9,70. Hasil penelitian di lapangan, dalam kegiatan evaluasi dan pelaporan, PPL melibatkan Gapoktan, Kelompok tani, dan petani. Hal ini dilakukan PPL karena PPL menyadari bahwa ketiga subjek tersebut merupakan

Tabel 5. Penilaian Tingkat Kinerja PPL dalam Program LDPM menurut Penilaian Petani di Kabupaten Banyuasin

\begin{tabular}{clrcrc}
\hline \multirow{2}{*}{ No } & \multirow{2}{*}{ Indikator } & \multicolumn{2}{c}{ K.Tani Madya } & \multicolumn{2}{c}{ K. Tani Lanjut } \\
\cline { 3 - 6 } & & Skor & Kriteria & Skor & Kriteria \\
\hline 1 & Kegiatan Penyuluhan Pertanian & 8,93 & Sedang & 10,03 & Sedang \\
2 & Pelaporan Dan Evaluasi & 8,67 & Sedang & 9,70 & Sedang \\
\hline \multicolumn{2}{l}{ Total } & 17,60 & Sedang & 19,73 & Sedang \\
\hline
\end{tabular}


satu kesatuan yang utuh.

\section{Tingkat Keberhasilan Program Lembaga Distribusi Pangan Masyarakat (LDPM)}

Untuk mengukur tingkat keberhasilan program LDPM ada 3 indikator yaitu : Hasil, Manfaat, dan Dampak. Tingkat keberhasilan program LDPM diukur menurut petani dan kelompok tani yang mengikuti program LDPM tersebut. Skor tingkat keberhasilan program LDPM dapat dilihat pada Tabel 6.

Tingkat keberhasilan dinilai penting dalam program LDPM . Hal itu disebabkan karena tingkat keberhasilan merupakan alat ukur yang digunakan untuk melihat sampai sejauh mana program LDPM itu telah terlaksana. tingkat keberhasilan program LDPM sangat ditentukan oleh kerjasama setiap pihakpihak yang terlibat. Ketersediaan cadangan pangan di lumbung LDPM ini masih terus ada meski pada masa paceklik. Hal tersebut terbukti karena banyak petani contoh yang mengakui bahwa di gudang penyimpanan milik Gapoktan Sri Rejeki tersedia cadangan pangan dan banyaknya petani yang melakukan penjualan gabah/beras ke lumbung pangan LDPM. Sehingga indikator hasil dari keseluruhan pengukuran tersebut memiliki skor total 7,96 dengan kriteria tinggi. Berdasarkan hasil pengukuran indikator manfaat untuk tingkat keberhasilan program ada tiga pengukuran yang dilakukan yaitu pengelolaan dana bansos, pengendalian harga gabah, dan akses pangan pada masa paceklik.

Pada program LDPM di Kecamatan Makarti Jaya, pengelolaan dana bansos masih dikelola dengan baik oleh Gapoktan. Berdasarkan hasil pengukuran indikator dampak untuk tingkat keberhasilan program ada tiga pengukuran yang dilakukan yaitu terkendalinya harga pangan pada masa paceklik, terwujudnya ketahanan pangan, dan peningkatan pendapatan petani. Pada masa paceklik harga pangan di daerah Gapoktan Kecamatan Makarti Jaya masih terkendali. Selain petani masih banyak yang memiliki cadangan pangan pribadi yang disimpan di lumbung pangan LDPM, harga beras jika membeli di lumbung sendiri tidak terlalu mahal. Selisih harga pada masa paceklik sekitar Rp. 500,00 hingga Rp. 1000,00 / Kg.

\section{Hubungan Kinerja Penyuluh Pertanian Lapangan dengan Tingkat Keberhasilan Program Lembaga Distribusi Pangan Masyarakat (LDPM)}

Dari penelitian yang telah dilaksanakan, kinerja Penyuluh Pertanian Lapangan (PPL) dan tingkat keberhasilan dalam program LDPM diolah dengan perhitungan skor. Hasil perhitungan skor tersebut lalu dibagi kedalam pembagian interval kelas, yang terdiri dari kriteria tinggi, sedang dan rendah. Berdasarkan hasil perhitungan, hubungan kinerja Penyuluhan Pertanian Lapangan (PPL) terhadap tingkat keberhasilan dalam program Lembaga Distribusi Pangan Masyarakat (LDPM) yang dianalisis dengan uji korelasi spearman dengan taraf nyata atau tingkat kepercayaan $(\alpha=0,05)$. Pada hasil perhitungan, diperoleh rs sebesar 0,48 sehingga didapat nilai z sebesar 3,18 sedangkan z tabel sebesar 1,960 yang berarti bahwa kaidah keputusan yang diambil adalah tolak Ho. Artinya ada hubungan antara kinerja PPL dengan tingkat keberhasilan program LDPM di Kecamatan Makarti Jaya Kabupaten Banyuasin. Hal ini berarti bahwa semakin tinggi kinerja PPL, maka akan semakin tinggi pula tingkat keberhasilan program LDPM tersebut.

Dari penelitian yang telah dilaksanakan dan dilakukan analisis, dapat dilihat bahwa PPL telah melaksanakan tugas dan fungsinya dalam kegiatan penyuluhan serta evaluasi dan pelaporan pada program LDPM, tetapi dalam melaksanakan tugas dan fungsinya PPL masih kurang maksimal sehingga kinerjanya berada pada kriteria sedang. Hal ini dikarenakan PPL yang menjadi penyuluh pendamping

Tabel 6. Tingkat Keberhasilan Program LDPM di Kabupaten Banyuasin

\begin{tabular}{clccc}
\hline No & Pengukuran & Skor & Kriteria \\
\hline 1. & Hasil & 7,96 & Tinggi \\
2. & Manfaat & 6,38 & Sedang \\
3. & Dampak & 7,25 & Tinggi \\
\hline Total & & 22,59 & Tinggi \\
\hline
\end{tabular}


pada tahap penumbuhan dan pengembangan dipindahtugaskan ke desa lain sehingga digantikan oleh Kepala BP3K Kecamatan Makarti Jaya.

Kinerja Kepala BP3K yang tugasnya sebagai penyuluh pendamping dalam program LDPM kurang maksimal. Selain tidak adanya surat kerja untuk melanjutkan pendampingan pada program LDPM, wilayah kerja Kepala BP3K yang juga luas menjadi faktor penyebab kinerja penyuluh pendamping pada kriteria sedang. Tetapidalam hal ini,PPLtidakmenutup mata akan program LDPM yang sedang dilaksanakan oleh Gapoktan Sri Rejeki. PPL masih memberikan bimbingan/pendampingan dan kegiatan evaluasi serta pelaporan meskipun hal tersebut dilakukan tidak dengan pelaksanaan yang intens. Sebaliknya tingkat keberhasilan program LDPM yang tinggi disebabkan karena baik Pengurus Lumbung LDPM dan petani saling bekerja sama untuk meningkatkan unit usaha yang mereka miliki. Pengurus lumbung LDPM sudah mandiri dalam mengurus setiap unit usaha yang dimiliki dan petani mendukung hal tersebut dengan selalu menjual gabah/beras ke lumbung LDPM.

\section{Kesimpulan}

Dari hasil penelitian yang telah dilakukan dapat disimpulkan bahwa tingkat kinerja Penyuluh Pertanian Lapangan (PPL) di Kecamatan Makarti Jaya Kabupaten Banyuasin tergolong dalam kriteria cukup dengan rata-rata Nilai Prestasi Kerja (NPK) sebesar 71,43. Kinerja PPL dalam program LDPM berdasarkan persepsi petani yang diukur melalui 2 indikator yaitu kegiatan penyuluhan pertanian dan evaluasi dan pelaporan tergolong dalam kriteria sedang dengan skor rata-rata tingkat kinerja PPL sebesar 19,0. Tingkat keberhasilan program LDPM di Kecamatan Makarti Jaya tergolong dalam kriteria tinggi dengan skor rata-rata tingkat keberhasilan sebesar 21,58 dan terdapat hubungan antara kinerja PPL dalam program LDPM dengan tingkat keberhasilan program LDPM di Kecamatan Makarti Jaya Kabupaten Banyuasin.

\section{Daftar Pustaka}

Armstrong, M. 2013. Performance Management. Terjemahan. Tony Setiawan. Tugu. Yogyakarta. Departemen Pertanian. 2010. Pedoman Teknis Kegiatan Program Lembaga Distribusi Pangan Masyarakat Tahun 2010.

Departemen Pertanian, 2006. Undang-Undang Republik Indonesia Nomor 16 Tahun 2006 tentang Sistem Penyuluhan Pertanian, Perikanan, dan Kehutanan. http://www.pekalongankab.go.id/peraturan/uuri/1558-uu-no16-tahun-2006-tentang-sistempenyuluhan-pertanian-perikanan-dan-kehutanan. html, (Diakses 30 November 2015).

Departemen Pertanian. 2010. Pedoman Umum Kegiatan Program Lembaga Distribusi Pangan Masyarakat Tahun 2010.

Jahi, Amri dan Ani, Leilani. 2006. Kinerja Penyuluh Pertanian di Beberapa Kabupaten, Provinsi Jawa Barat. Jurnal Penyuluhan. Vol. 2 No.2.

Khudori. Political Will Pemerintah Dalam Mewujudkan Kedaulatan Pangan Melalui Diversifikasi Pangan, Makalah disampaikan dalam Seminar Mewujudkan Kedaulatan Pangan Indonesia Melalui Diversifikasi Pangan. UGM Yogyakarta.

Lubis, Linda Jannahari. 2014. Faktor-Faktor yang Berhubungan dengan Keberhasilan Penguatan Lembaga Distribusi Pangan Masyarakat (P-LDPM) di Kabupaten Serdang Bedagai, Tesis S2. Fakultas Pertanian Universitas Sumatara Utara, Medan.

Maulid Sari, Awal. Kinerja Penyuluh Pertanian Dalam Pengembangan Usaha Peternakan Sapi Bali Di Kabupaten Muna Provinsi Sulawesi Tenggara, Tesis S2. Universitas Udayana. Denpasar.

Peraturan Pemerintah No.68. 2002. Ketahanan Pangan sebagai peraturan pelaksanaan UU No.7 tahun 1996 Sukmadinata, N. S, 2011. Metode Penelitian Pendidikan. PT. Remaja Rosdakarya Offset. Bandung. 